\title{
THE EFFECT OF PREGNANCY EXERCISE ON THE
} SMOOTH DELIVERY OF THE SECOND STAGE OF CHILDBIRTH PROCESS IN EKA MEDIKA PRATAMA CLINIC, PUNGGING VILLAGE, MOJOSARI SUB-DISTRICT,
MOJOKERTO DISTRICT

\author{
Titiek Idayanti ${ }^{1 *}$, Siti Fithrotul Umami ${ }^{2}$ \\ ${ }^{1}$ STIKES Dian Husada Mojokerto \\ ${ }^{2}$ Ar-Rahma Midwifery Academy \\ *Correspondence: \\ Titiek Idayanti \\ Email: ti2k.nurul@gmail.com
}

\begin{abstract}
Background: In childbirth, there are several factors that can affect the smooth delivery of the second stage, one of which is influenced by straining factors that can be anticipated by doing pregnancy exercise, in which pregnancy exercise can affect the slow pace of the second stage of childbirth process.

Objectives: The purpose of this study was to determine the effect of pregnancy exercise on the smooth delivery of the second stage of childbirth process in Eka Medika Pratama Clinic, Pungging Village, Mojosari Sub-District, Mojokerto District.

Method: The method used in this study is analytic with a case control approach using research instruments in the form of questionnaires and observation sheets with a check list. The sample is some of the mothers who do pregnancy exercise and do not do pregnancy exercise during pregnancy in Eka Medika Pratama Clinic, Pungging Village, Mojosari Sub-District, Mojokerto District.

Results: The results of data collection were processed by chi-square statistical test $\left(\mathrm{X}^{2}\right)$ with a significance level of $\alpha=0.05$. The results of the study showed a significant relationship between pregnancy exercise and the smoothness of the second stage of childbirth process with a value of $\mathrm{P}=0.007$.

Conclusion: Most of the respondents who do pregnancy exercise undergo the second stage of childbirth process more quickly than mothers who are not doing pregnancy exercise. Suggestions given in the results of this study are expected midwives provide counseling to pregnant women about the importance of doing pregnancy exercise during pregnancy to facilitate the second stage of childbirth process.
\end{abstract}

Key words: Pregnancy exercise, smooth delivery, second stage of childbirth process.

\section{INTRODUCTION}

Maternal Mortality Rate (MMR) in Indonesia is still relatively high when compared to countries in ASEAN, which is around 373 per 100,000 births in 1995. This figure is around 3 - 6 times greater than the countries in the ASEAN region and more than 50 times that of figures in developed countries (Departemen Kesehatan, 2000). The cause of maternal death is due to bleeding, infection, anemia, gestational pre-eclampsia and eclampsia
(Manuaba, 1998). According to a 1997 health survey, the highest risk of death was due to bleeding (42\%), eclampsia (13\%), infection (10\%) prolonged labor (11\%), abortion complications $(11 \%)$ and the rest due to indirect causes (Departemen Kesehatan, 2000).

In childbirth, both physiological and pathological, there are several important factors that can affect the course of childbirth, including the strength of contractions of the uterine muscles in childbirth, diaphragmatic 
pelvic force or contraction, tension or contraction of the rotundum, ligament and passenger (fetus and placenta) and passage (soft birth canal and bone birth canal) (Manuaba, 1998). In dealing with prolonged childbirth or prolonged childbirth caused by problems of power or strength can be handled by increasing energy or strength through pregnancy exercise.

Pregnancy exercise is an exercise program for healthy pregnant women to prepare for the physical condition of the mother by maintaining the condition of the muscles and joints that play a role in the delivery process. Pregnancy exercise benefit the biomotor components of the muscles that are trained and can also increase cardiorespiratory endurance by increasing oxygen consumption with pregnancy exercise regularly, if there is no pathological state it can lead pregnant women towards physiological childbirth (Manuaba, 1998). Research conducted by Denpasar Sanglah Hospital showed that the incidence of prolonged childbirth process in non-exercise cases was $15.1 \%$ and in the case of exercise there were $1.9 \%$ of 106 maternity mothers (Susiloningtyas, 2017).

Preliminary studies conducted by researchers showed that maternity mothers experienced obstacles during the second stage of childbirth, which is about $40 \%$ of 20 deliveries.

\section{METHODS}

\section{Study Design}

The research design used is analytic by using a case control approach wherein in this study the effect variables, namely pregnancy exercise, were identified at this time and then risk factors, namely the second stage of childbirth, identified the existence or occurrence in the past.

\section{Setting}

This research was conducted in Eka Medika Pratama Clinic, Pungging Village, Mojosari Sub-District, Mojokerto District.

\section{Research Subject}

The population of this study were all pregnant women who participated in pregnancy exercise and did not do pregnancy exercise during their pregnancy in Eka Medika Pratama Clinic, Pungging Village, Mojosari SubDistrict, Mojokerto District. The sample of this study was some of the mothers who were pregnant and did not do pregnancy exercise during their pregnancy in Eka Medika Pratama Clinic, Pungging Village, Mojosari SubDistrict, Mojokerto District. The sampling technique used is purposive sampling.

\section{Instrument}

Collecting data in this study using primary and secondary data sources. The instruments used were past labor records, and a history of pregnancy control which included a history of pregnancy exercises, as well as a record of the process of the second stage of childbirth process.

\section{Data Analysis}

The results of this study were analyzed using the Chi Square Statistical Test with value of $\alpha=0.05$.

\section{RESULTS}

Characteristics of Respondents by Age of Pregnant Women

Table 1. Distribution of Respondents by Age of Pregnant Women in Eka Medika Pratama Clinic, Pungging Village, Mojosari SubDistrict, Mojokerto District $(\mathrm{n}=30)$.

\begin{tabular}{lcc}
\hline \multicolumn{1}{c}{ Umur } & Frekuensi (f) & Persentase $(\boldsymbol{\%})$ \\
\hline$<20$ years & 4 & 13.3 \\
$20-30$ years & 20 & 66.7 \\
$>30$ years & 6 & 20 \\
\hline Total & $\mathbf{3 0}$ & $\mathbf{1 0 0}$ \\
\hline
\end{tabular}

Sources: Primary Data

Based on Table 1, the majority of pregnant women in Eka Medika Pratama Clinic, Pungging Village, Mojosari Sub-District, Mojokerto District aged 20-30 years were 20 respondents $(66.7 \%)$.

Characteristics of Respondents by Level of Education of Pregnant Women

Based on table 2, half of pregnant women in Eka Medika Pratama Clinic, Pungging Village, Mojosari Sub-District, Mojokerto District were educated with Senior High School as many as 16 respondents $(53.3 \%)$. 
Table 2. Distribution of Respondents by Level of Education of Pregnant Women in Eka Medika Pratama Clinic, Pungging Village, Mojosari Sub-District, Mojokerto District ( $\mathrm{n}=$ $30)$.

\begin{tabular}{lcc}
\hline Level of Education & Frequency (f) & Percentage (\%) \\
\hline Elementary School & 3 & 10 \\
Junior High School & 6 & 20 \\
Senior High School & 16 & 53.3 \\
University & 5 & 16.7 \\
\hline Total & $\mathbf{3 0}$ & $\mathbf{1 0 0}$
\end{tabular}

Sources: Primary Data

Characteristics of Respondents by Occupational of Pregnant Women

Table 3. Distribution of Respondents by Occupational of Pregnant Women in Eka Medika Pratama Clinic, Pungging Village, Mojosari Sub-District, Mojokerto District ( $\mathrm{n}=$ $30)$.

\begin{tabular}{lcc}
\hline \multicolumn{1}{c}{ Occupational } & Frequency (f) & Percentage (\%) \\
\hline Housewives & 22 & 73.3 \\
Entrepreneurs & 7 & 23.3 \\
Government & 1 & 3.4 \\
Employees & & \\
\hline Total & $\mathbf{3 0}$ & $\mathbf{1 0 0}$ \\
\hline Sources: Primary Data & &
\end{tabular}

Based on Table 3, the majority of pregnant women in Medika Pratama Eka Clinic, Pungging Village, Mojosari Sub-District, Mojokerto District have their occupations status are housewives as many as 22 respondents $(73.3 \%)$.

Distribution of Respondents based on Age in the Implementation of Pregnancy Exercise

Table 4. Distribution of Respondents based on Age in the Implementation of Pregnancy Exercise in Eka Medika Pratama Clinic, Pungging Village, Mojosari Sub-District, Mojokerto District $(\mathrm{n}=30)$.

\begin{tabular}{lcccccc}
\hline \multirow{2}{*}{ Age } & \multicolumn{5}{c}{ Pregnancy Exercise } \\
\cline { 2 - 7 } & \multicolumn{2}{c}{ Implement } & $\begin{array}{c}\text { Not } \\
\text { Implement }\end{array}$ & \multicolumn{2}{c}{ Total } \\
\cline { 2 - 7 } & $\mathrm{F}$ & $(\%)$ & $\mathrm{F}$ & $(\%)$ & $\mathrm{F}$ & $(\%)$ \\
\hline < 20 years & 2 & 13.3 & 2 & 13.3 & 4 & 13.3 \\
20 - 30 years & 9 & 60 & 11 & 73.4 & 20 & 66.7 \\
$>30$ years & 4 & 26.7 & 2 & 13.3 & 6 & 20 \\
\hline Total & 15 & 100 & 15 & 100 & 30 & 100 \\
\hline
\end{tabular}

Sources: Primary Data and Secondary Data

Based on table 4, the majority of respondents in this study were 20-30 years old as many as 20 respondents $(66.7 \%)$. At that age, most of the respondents did not do pregnancy exercise as many as 11 people $(73.4 \%)$ out of 15 respondents who did not do pregnancy exercise and only 9 respondents (60\%) did pregnancy exercise from 15 respondents who performed pregnancy exercise.

Distribution of Respondents based on Level of Education in the Implementation of Pregnancy Exercise

Table 5. Distribution of Respondents based on Level of Education in the Implementation of Pregnancy Exercise in Eka Medika Pratama Clinic, Pungging Village, Mojosari SubDistrict, Mojokerto District $(\mathrm{n}=30)$.

\begin{tabular}{lcccccc}
\hline & \multicolumn{5}{c}{ Pregnancy Exercise } \\
\cline { 2 - 7 } Level of Education & \multicolumn{7}{c}{ Implement } & $\begin{array}{c}\text { Not } \\
\text { Implement }\end{array}$ & Total \\
& \multicolumn{7}{c}{ F } & $(\%)$ & $\mathrm{F}$ & $(\%)$ & $\mathrm{F}$ & $(\%)$ \\
\hline Elementary School & 0 & 0 & 3 & 20 & 3 & 10 \\
Junior High School & 3 & 20 & 3 & 20 & 6 & 20 \\
Senior High School & 10 & 66.7 & 6 & 40 & 16 & 53.3 \\
University & 2 & 13.3 & 3 & 20 & 5 & 16.7 \\
\hline Total & 15 & 100 & 15 & 100 & 30 & 100 \\
\hline Sources: Primary Data and Secondary Data
\end{tabular}

Based on table 5, half of the respondents with Senior High School education were 17 respondents. At this level of education, respondents who performed pregnancy exercise were 10 respondents $(66.7 \%)$ of the 15 respondents who performed pregnancy exercise and the remaining 6 respondents $(40 \%)$ of the 15 respondents who did not do pregnancy exercise.

Distribution of Respondents based on Occupational in the Implementation of Pregnancy Exercise

Table 6. Distribution of Respondents based on Occupational in the Implementation of Pregnancy Exercise in Eka Medika Pratama Clinic, Pungging Village, Mojosari SubDistrict, Mojokerto District $(\mathrm{n}=30)$.

\begin{tabular}{lcccccc}
\hline & \multicolumn{5}{c}{ Pregnancy Exercise } \\
\cline { 2 - 7 } Occupational & Implement & \multicolumn{2}{c}{$\begin{array}{c}\text { Not } \\
\text { Implement }\end{array}$} & \multicolumn{2}{c}{ Total } \\
\cline { 2 - 7 } & $\mathrm{F}$ & $(\%)$ & $\mathrm{F}$ & $(\%)$ & $\mathrm{F}$ & $(\%)$ \\
\hline Housewives & 12 & 80 & 10 & 66.7 & 22 & 73.3 \\
Entrepreneurs & 3 & 20 & 4 & 26.7 & 7 & 23.3 \\
Government & 0 & 0 & 1 & 6.6 & 1 & 3.4 \\
employees & \multicolumn{7}{c}{100} & & & & \\
\hline Total & 15 & 100 & 30 & 100 \\
\hline Sources: Primary Data and Secondary Data
\end{tabular}


Based on table 6, most respondents were housewives as many as 22 respondents $(73.3 \%)$. In these conditions, the majority of the respondents performed pregnancy exercise as many as 12 respondents (80\%) of the 15 respondents who did pregnancy exercise and there were 10 respondents $(66.7 \%)$ did not do pregnancy exercise from 15 respondents who did not do pregnancy exercise.

Distribution of Respondents in the Implementation of Pregnancy Exercise

Table 7. Distribution of Respondents in the Implementation of Pregnancy Exercise in Eka Medika Pratama Clinic, Pungging Village, Mojosari Sub-District, Mojokerto District ( $\mathrm{n}=$ $30)$.

\begin{tabular}{lcc}
\hline $\begin{array}{c}\text { Pregnancy } \\
\text { Exercise }\end{array}$ & Frequency (f) & Percentage (\%) \\
\hline Implement & 15 & $50 \%$ \\
Not Implement & 15 & $50 \%$ \\
\hline Total & 30 & 100 \\
\hline Sources: Secondary Data & &
\end{tabular}

The results of the research data in table 7 show that the number of respondents between those who did pregnancy exercise and those who did not do pregnancy exercise were 15 respondents.

Distribution of Respondents based on The Smooth Delivery Process at the Second Stage

Table 8. Distribution of Respondents based on the Smooth Delivery Process at Second Stage in Eka Medika Pratama Clinic, Pungging Village, Mojosari Sub-District, Mojokerto District $(\mathrm{n}=30)$.

\begin{tabular}{lcc}
\hline Criteria & Frequency (f) & Percentage (\%) \\
\hline Smoothly & 20 & $66.7 \%$ \\
Not Smooth & 10 & $33.3 \%$ \\
\hline Total & $\mathbf{3 0}$ & $\mathbf{1 0 0}$ \\
\hline Sources: Secondary Data &
\end{tabular}

The results of the study in table 8 show that the majority $(66.7 \%)$ of respondents experienced a smooth delivery process at the second stage of childbirth process.
The Effect of Pregnancy Exercise on the Smooth Delivery of the Second Stage of Childbirth Process in Eka Medika Pratama Clinic, Pungging Village, Mojosari SubDistrict, Mojokerto District

Table 9. Examination of The Effect of Pregnancy Exercise on the Smooth Delivery of the Second Stage of Childbirth Process in Eka Medika Pratama Clinic, Pungging Village, Mojosari Sub-District, Mojokerto District ( $\mathrm{n}=$ $30)$.

\begin{tabular}{lcccccc}
\hline & \multicolumn{5}{c}{$\begin{array}{c}\text { Smooth Delivery Process at the Second } \\
\text { Stage of Childbirth Process }\end{array}$} \\
\cline { 2 - 7 } $\begin{array}{c}\text { Pregnancy } \\
\text { Exercise }\end{array}$ & \multicolumn{3}{c}{ Smoothly } & Not Smooth & \multicolumn{1}{c}{ Total } \\
\cline { 2 - 7 } & $\mathrm{F}$ & $(\%)$ & $\mathrm{F}$ & $(\%)$ & $\mathrm{F}$ & $(\%)$ \\
\hline Implement & 14 & 70 & 1 & 10 & 15 & 50 \\
Not Implement & 6 & 30 & 9 & 90 & 15 & 50 \\
\hline Total & 20 & 100 & 10 & 100 & 30 & 100 \\
\hline $\mathrm{X}^{2}$ Count $=7.350 ; \mathrm{X}^{2}$ table $=3.841 ; p=0.007<\alpha=0,05$ \\
\hline Sources: Secondary Data
\end{tabular}

From the research data in table 9 it was found that respondents who performed pregnancy exercise underwent a smooth delivery process as many as 14 respondents (70\%) and who underwent a non-smooth delivery process as many as 1 respondent $(10 \%)$. And respondents who did not do pregnancy exercise who underwent a smooth delivery process were 6 respondents $(30 \%)$ and who underwent a non-smooth delivery process as many as 9 respondents (90\%).

From the results of the chi-square test, obtained $\mathrm{X}^{2}$ count $=7.350$ more than $\mathrm{X}^{2}$ table $=$ $3.841, p$ value found 0.007 which means smaller than $\alpha=0.05$, then Ho is rejected and $\mathrm{Hi}$ is accepted so it can be concluded that there is pregnancy exercise affect to smooth delivery process at the second stage of childbirth.

\section{DISCUSSION}

Characteristic of Respondents by Age of Pregnant Women in Eka Medika Pratama Clinic, Pungging Village, Mojosari SubDistrict, Mojokerto District

The results showed that the majority of pregnant women who do pregnancy exercise are aged 20-30 years, because with a young age the ability to learn and receive stimuli about giving pregnancy exercise information will be good. Whereas for mothers who are less than 20 years old, the mother may not know about the importance of pregnancy exercise and the lack of information obtained, especially about 
pregnancy exercise in her pregnancy. Mothers who are more than 30 years old who already have children are likely to be lazy to do pregnancy exercise because they have no problems in the first childbirth delivery process and they are busy taking care of the child so that the mother has no time to do pregnancy exercise in her pregnancy. According to Chatarina (2004), mothers over the age of 30 years and are married have little time to spare for the many activities that take time either within the family or activities outside the home, so it can be concluded that pregnant women who are older than 30 years and have children are lazy to do pregnancy exercise in her pregnancy.

This is in accordance with the theory of Notoatmodjo (2002) which states that age can influence respondents' knowledge, this is as a result of increasing age, the level of maturity of a person will be better at thinking and working.

Based on the results of the study, more pregnant women aged 20-30 years who do pregnancy exercise in accordance with the procedure than pregnant women who do not do pregnancy exercise. Pregnant women who do not do pregnancy exercise in accordance with the procedure due to their ability to learn and receive stimuli are still poorly understood.

Characteristic of Respondents by Level of Education of Pregnant Women in Eka Medika Pratama Clinic, Pungging Village, Mojosari Sub-District, Mojokerto District

Based on education, the majority of respondents with senior high school education, where at the level of education, are generally able to receive information on pregnancy exercise.

This is consistent with the theory of Notoatmodjo (2002) which states that the level of higher education has a different knowledge from people who are only low educated, and also stated that the higher the level of education a person, the easier the person receives information from other people and the mass media, but there are mothers who have a high level of education (college graduates) who do not do pregnancy exercise in their pregnancy. These conditions can be influenced by several factors, including mothers busy working outside the home so that there is no time to do pregnancy exercise, lack of information both obtained from health workers and from the mass media and others. According to Ahmadi (1997), the knowledge gained through human thought or reason that is possessed as a result of the use of the five senses which are also related to education.

In this case one's education does not affect pregnancy exercise, because from the results of the study it was found that all pregnant women from different educational backgrounds both high and low can do pregnancy exercise. So the higher the level of education a person does not necessarily do pregnancy exercise. According to Kusmiati (1996), the level of education is very influential on the level of knowledge, the higher one's education, the better his ability to absorb information received. This contrasts with the results obtained from studies that mothers who do pregnancy exercise from educational backgrounds different to do pregnancy exercise.

Characteristic of Respondents by Occupational of Pregnant Women in Eka Medika Pratama Clinic, Pungging Village, Mojosari SubDistrict, Mojokerto District

Based on the results of the study most of the respondents were housewives where housewives had a lot of time to do pregnancy exercise which was obtained during visits in Private Practice Midwives and in Auxiliary Health Centers. Whereas working mothers are usually busy with their work, so sometimes they are not able to do pregnancy exercises performed in Private Practice Midwives or in the Auxiliary Health Center. According to Thomas (1996) in Nursalam (2001), work generally takes time so that it can affect other things including also knowing something outside of his work. This is an opportunity and opportunity for pregnant housewives who have more time to know, find information both obtained from health workers and from other media, and pregnant women can apply pregnancy exercise during pregnancy. In accordance with the results of the study, the majority of housewives performed pregnancy exercise at home, which was obtained from antenatal care visits (ANC) in Private Practice Midwives and in Auxiliary Health Centers. 
Characteristic of Respondents in the Implementation of Pregnancy Exercise of Pregnant Women in Eka Medika Pratama Clinic, Pungging Village, Mojosari SubDistrict, Mojokerto District

Based on the results of the study showed that pregnancy exercise performed by pregnant women in Eka Medika Pratama Clinic, Pungging Village, Mojosari Sub-District, Mojokerto District. Most of them have fulfilled the requirements/ according to procedures even though there are still those who do pregnancy exercises that are not according to procedures.

Of the respondents who did pregnancy exercise, most did not take steps to lift the right leg to the side of the abdomen - left hand under the thigh, arching the back and directing the head and pelvis forward. This is because maternity mothers do not understand the steps that function is to facilitate the second stage of childbirth process. This does not have a major effect on the smooth running of the second stage of childbirth process when the mother performs 7 movements from the 8 existing movements, because in normal childbirth there are several factors that affect the second stage of childbirth process, one of which is the power that can be anticipated by doing pregnancy exercise.

Characteristic of Respondents based on The Smooth Delivery Process at the Second Stage

In the maternity data, 15 women who participated in pregnancy exercise found that the average mother gave birth to the second stage of childbirth process more smoothly than the mother who did not participate in pregnancy exercise because the mother followed the pregnancy exercise more ready to face childbirth and when the childbirth process took place the mother is stronger or the mother can push strongly and correctly so that when II is smoother. According to Curtis (1999), a mother who performs pregnancy exercise in her pregnancy will strengthen the muscles needed to give birth so as to facilitate childbirth.

The Effect of Pregnancy Exercise on the Smooth Delivery of the Second Stage of Childbirth Process in Eka Medika Pratama Clinic, Pungging Village, Mojosari SubDistrict, Mojokerto District

Based on the results of the study, pregnant women who perform pregnancy exercises that are in accordance with the procedure will experience a second stage of childbirth process that is smoother. The birth process is said to be fast or smooth if the time required is between 11.5 hours for primigravida and 1/2 - 1 hour for multigravida conditions (Manuaba, 1998). Whereas those who do not exercise pregnancy or do but do not comply with the procedure, the second stage of childbirth process is not smooth. The childbirth process is said to be slow / less smooth if primigravida is more than $1 \frac{1}{2}$ hours, multigravida is more than 1 hour (Manuaba, 1998). Based on the results of the study, there were some respondents who did pregnancy exercise according to the procedure, but in the second stage of childbirth process they tended to be slow / not smooth. This can be influenced by many things, including maternal condition, poor nutrition, and lack of rest. In addition, it can also be influenced by other factors, including passage, passanger, helper, and psychological parturients that affect the smooth delivery process at the second stage. Although pregnancy exercise is carried out in accordance with the procedure but if the mother's nutrition is poor, the mother's condition is not healthy, the rest is lacking, and other factors that affect the smooth delivery process, it will affect the second stage of childbirth process. So the conclusion is other than pregnancy exercise, many factors influence the smoothness of the second stage of childbirth process.

This is in accordance with the results of data analysis with a chi-square test which shows a significant influence between pregnancy exercise with the second stage of labor so that it can be seen that the value of $p=$ 0.007 or less than the value of $\alpha=0.05$.

\section{CONCLUSION}

Based on the results of the study there are several things that can be concluded, among others:

1. The influence of pregnancy exercise with the smooth delivery process at the second stage. And the majority of the mothers who gave pregnancy exercise according to the procedure were 13 respondents.

2. Pregnancy exercise performed by pregnant women is seen based on several characteristics, including: 
a. The most age-based characteristics of pregnancy exercise are 20-30 years and at least less than 20 years old.

b. Characteristics based on education level are known that the number of mothers who perform pregnancy exercise is the most, with high school education and at least elementary school education.

c. Based on characteristics revealed that mothers who performed pregnancy exercise were mostly housewives.

3. The childbirth process is influenced by several factors, one of which is influenced by straining strength factors that can be anticipated by doing pregnancy exercise. Pregnant women who perform pregnancy exercise in their pregnancies according to the procedure will undergo a second stage of childbirth faster than mothers who do not perform pregnancy or do exercises but do not comply with the procedure.

\section{SUGGESTION}

1. This research can be used as material for consideration of the need to provide information about pregnancy exercise in mothers who are very useful in developing the insight of the mothers so as to reduce the occurrence of things that are not desirable during childbirth, especially the second stage of childbirth process.

2. Providing minimal counseling every week for pregnant women every time ANC at least 5 months of gestation about the benefits of doing pregnancy exercise in pregnancy and childbirth with the aim of increasing the knowledge of pregnant women about the importance of pregnancy exercise during pregnancy until the second stage of childbirth process in Eka Medika Pratama Clinic, Pungging Village, Mojosari Sub-District, Mojokerto District.

3. Provide brochures about pregnancy exercises that use services Eka Medika Pratama Clinic, Pungging Village,
Mojosari Sub-District, Mojokerto District.

4. Demonstrate and teach pregnancy exercises that are in accordance with the procedures of pregnant women who have performed pregnancy exercise but are not in accordance with the procedure and who have never done pregnancy exercise the importance of doing pregnancy exercise in pregnancy and childbirth that can be done in Eka Medika Pratama Clinic, Pungging Village, Mojosari Sub-District, Mojokerto District pada saat ANC.

5. It is expected that the results of this study can be used as a reference in the future for future researchers with more sample coverage with the hope that the results of future research will be better.

\section{REFERENCES}

Curtis, Glade. (2000). Kehamilan Diatas 30. Jakarta : Departemen Kesehatan.

Curtis, Glade. (2002). Apa Yang Anda Hadapi Minggu Per Minggu. Jakarta: Departemen Kesehatan.

Departemen Kesehatan. (2000). Standart Pelayanan Kebidanan. Jakarta: Dapertemen Kesehatan.

Huliana, Mellyna. (2001). Panduan Menjalani Kehamilan Sehat. Jakarta: Puspa Swara.

Manuaba, Ida Bagus Gde. (1998). Ilmu Kebidanan Penyakit Kandungan dan Keluarga Berencana Untuk Bidan. Jakarta: EGC.

Manuaba, Ida Bagus Gde. (1999). Operasi Kebidanan Kandungan dan Keluarga Berencana Untuk Dokter Umum. Jakarta: EGC.

Mochtar, Rustam. (1998). Synopsis Obstetri. Edisi 2. Jakarta: EGC.

Notoatmodjo, Sukidjo. (2002). Metodologi Penelitian Kesehatan. Jakarta: Rineka Cipta.

Notoatmodjo, Sukidjo. (2005). Metodologi Penelitian Kesehatan. Jakarta: Rineka Cipta.

Nursalam, dkk. (2001). Pendekatan Praktis Metodologi Riset Keperawatan. Jakarta: Salemba Medika.

Prawirohardjo, Sarwono. (1999). Ilmu Kebidanan. Jakarta: Tridasa Printer.

Sumapraja, Sudraji. (2002). Persalinan Normal. Jakarta: Balai Penerbit FKUI. 
Supriatmaja. (2003). Pengaruh Senam Hamil Terhadap Persalinan Kala Satu dan Kala Dua. Retrieved at January 22, 2007 from www.Kalbefarma.com.

Susiloningtyas, L. (2017). HUBUNGAN

SENAM HAMIL DENGAN

KELANCARAN PROSES

PERSALINAN KALA II PADA

PRIMIGRAVIDA. Jurnal Science

Midwifery, 1(1).

Tim Penyusun Kamus Pusat Bahasa. (2005).

Kamus Besar Bahasa Indonesia. Jakarta:

Balai Pustaka.

Cite This Article As: Idayanti, T. \& Umami, $S$. F. The Effect of Pregnancy Exercise on The Smooth Delivery of The Second Stage of Childbirth Process in Eka Medika Pratama Clinic, Pungging Village, Mojosari Sub-District, Mojokerto District. Nurse and Health: Jurnal Keperawatan 2018; 7(2): 133140 . 